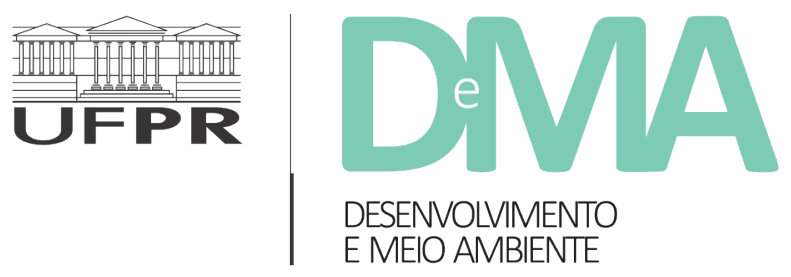

\title{
Reservas Extrativistas Marinhas à luz da representação social de pescadores artesanais do litoral centro-sul de Santa Catarina
}

\section{Marine Extractive Reserves in the light of the social representation of artisanal fishermen on the coast of Santa Catarina}

\author{
Melissa VIVACQUA ${ }^{1 *}$, Helio de Castro Lima RODRIGUES ${ }^{2}$ \\ ${ }^{1}$ Departamento de Ciências do Mar (DCMar), Universidade Federal de São Paulo (UNIFESP), Santos, SP, Brasil. \\ ${ }^{2}$ Consultor do Programa das Nações Unidas para o Desenvolvimento (PNUD), Instituto Chico Mendes de Conservação da Biodiversidade \\ (ICMBio), Brasília, DF, Brasil.
}

*E-mail de contato: melviva@hotmail.com

Artigo recebido em 9 de abril de 2018, versão final aceita em 6 de setembro de 2018.

RESUMO: A política pública Reserva Extrativista tem passado por profundas transformações desde a sua concepção no seio do movimento social dos seringueiros. A transposição deste modelo para o bioma marinho trouxe novos desafios tanto para os processos de criação quanto para a implementação dos diferentes instrumentos de gestão. Nesse sentido, o presente artigo tem o objetivo de refletir sobre a etapa de pré-implementação das Resex a partir do estudo da representação social dos pescadores artesanais sobre Reserva Extrativista. A pesquisa foi realizada no litoral centro-sul de Santa Catarina, onde há dois processos de criação de Reservas Extrativistas parcialmente sobrepostas ao território da Área de Proteção Ambiental da Baleia Franca (APA BF): a Reserva Extrativista do Farol de Santa Marta e a Reserva Extrativista da Pesca Artesanal de Imbituba e Garopaba. Os dados necessários à pesquisa foram apreendidos por meio de 60 entrevistas semiestruturadas com pescadores artesanais dos dois contextos. Os resultados revelam a existência de duas representações sociais sobre reserva extrativista. Para o grupo de pescadores favorável à criação da Resex, ela representa uma estratégia para regulamentar a gestão dos recursos pesqueiros a fim de afastar os barcos industriais da costa; e para o grupo contrário, a Resex significa perda de território e autonomia para as agências ambientais, representada localmente pela APA BF, bem como, a defesa de um modo de vida baseado no extrativismo, o qual já não representa a realidade do pescador artesanal da região. Desse modo, o conteúdo dessas representações sociais revela que, mesmo finalizado o processo formal junto às 
comunidades locais, permanece entre os pescadores visões antagônicas e parciais acerca do significado e implicações do processo de criação e implementação dessa política pública.

Palavras-chave: Reserva Extrativista; representação social; pescador artesanal; conflito socioambiental.

ABSTRACT: As a public policy, the Extractive Reserve has undergone profound transformations since its conception within the rubber tappers social movement. The transposition of this model to the marine biome has introduced new challenges both for the creation processes and for the implementation of different management tools. This article aims to reflect on the pre-implementation stage of Resex based on the the study of the social representation of artisanal fishermen on that protected area category. The research was carried out in the south-central coast of Santa Catarina, where there are two processes of creation of Extractive Reserves partially superimposed on the territory of the Environmental Protection Area of the Baleia Franca: the Extractive Reserve of the Lighthouse of Santa Marta and the Extractive Reserve of Artisanal Fishing of Imbituba and Garopaba. Data were obtained through 60 interviews with artisanal fishermen from both contexts. The results reveal the existence of two social representations about extractive reserves. The content of these social representations reveals that even when the formal process is concluded with the local communities participation, there remain, among the fishermen, antagonistic and partial visions about the meaning and implications of the process of creation and implementation of this public policy.

Keywords: extractive reserve; social representation; artisanal fisherman; socio-environmental conflict.

\section{Introdução}

As Reservas Extrativistas (Resex), diferentemente das outras categorias de unidades de conservação, têm sua gênese no âmbito do movimento social dos seringueiros na Amazônia, no decorrer das décadas de 1980-90. Inicialmente criada para mitigar os conflitos fundiários na floresta amazônica, foi somente a partir da década de 1990 que o conceito de Resex se consolida enquanto política pública. No ano de 1992, no contexto da Conferência ECO-92, a política das Resex se expande para outros biomas, incluindo a zona costeira.

A conexão entre as demandas do movimento social dos seringueiros e do movimento ambientalista, e a posterior normatização da Resex pelo Sistema Nacional de Unidades de Conservação - SNUC (Brasil, 2000a), colocam em relevo o desafio da integração dos objetivos e demandas de dois movimentos sociais. Tais movimentos, apesar de guardarem grande potencial sinérgico, possuem histórico e lutas distintas, havendo o risco da dimensão da conservação da biodiversidade prevalecer sobre a luta dos seringueiros pela autonomia no uso do território e a valorização dos seus saberes no processo de desenvolvimento da Amazônia (Allegretti, 2002).

No contexto do bioma marinho, as Resex dispõem de um expressivo potencial para se fortalecer um processo de gestão compartilhada de base comunitária (Pomeroy \& Rivera-Guieb, 2006), norteada pelos saberes e autonomia dos diferentes grupos de pescadores artesanais. Contudo, há evidências de que a maneira com que as Resex vêm sendo criadas e implementadas na zona marinhocosteira explicita uma constante tensão entre os modos de vida das populações locais e as estratégias de conservação da biodiversidade (Lobão, 2010).

Atualmente existem 24 Resex Marinho-Costeiras (Resex Mar) criadas e 51 demandas de criação 
no âmbito do governo federal ${ }^{1}$. Desde o processo de estabilização institucional, com o advento do SNUC, as Resex foram sendo consolidadas por meio de diversos instrumentos de gestão territorial, a exemplo dos Conselhos Gestores, Planos de Manejo, entre outros. Como apontam Seixas \& Kalikoski (2009), não há muitas pesquisas que tragam subsídios para se avaliar os resultados que essas Resex apresentam tanto em termos socioculturais quanto estritamente ambientais. Contudo, os trabalhos existentes evidenciam os conflitos e desafios inerentes aos processos de gestão das Resex Mar (Bucci, 2009; Chamy, 2004; Lobão, 2010; 2000; Nicolau, 2006; Pinto da Silva, 2004; Spínola, 2011). A centralidade dessas análises recai sobretudo nos processos de implementação das Resex, ficando a etapa "pré-implementação" relegada aos aspectos descritivos. Como apontam Chuenpagdee \& Jentof (2007), pouca atenção tem sido dada à etapa pré-implementação (step zero) dos diferentes arranjos de gestão compartilhada, e muitos desafios identificados nos processos de implementação podem ser atribuídos à maneira como as fases iniciais são conduzidas.

Ao deslocar o foco para a etapa pré-implementação, vale a pena iluminar as concepções que impulsionaram a criação das Resex no âmbito do movimento social dos seringueiros. Como aponta Allegretti (2002), um dos aspectos fundamentais da proposta era a criação de projetos extrativistas onde houvesse uma organização prévia das comunidades e não somente onde o governo pretendesse eliminar focos de tensão. Para os seringueiros essa organização prévia era um requisito fundamental para assegurar o sucesso da Resex após a sua criação.
Durante o Seminário "O Desenvolvimento da Amazônia e a Questão Ambiental”, em fevereiro de 1988, Chico Mendes chamou atenção para alguns pré-requisitos fundamentais para o processo de criação de Resex: áreas onde há a presença de conflitos; os seringueiros devem estar organizados; existência de infraestrutura comunitária; e ter ideia do que é uma reserva extrativista. Em sua fala Chico Mendes demonstrou o receio de que se implantasse uma reserva em áreas onde não existisse um mínimo de organização, colocando em xeque as possibilidades do sucesso da Resex e fragilizando todo o trabalho desenvolvido junto aos seringueiros (Allegretti, 2002).

Com a institucionalização das Resex, aquilo que outrora chamou a atenção do líder seringalista, foi colocado à prova, sobretudo a partir do novo arcabouço legal do Sistema Nacional de Unidades de Conservação (SNUC), promulgado em 2000. Antes disso, os processos de criação de Resex eram conduzidos pelo Centro Nacional de Populações Tradicionais (CNPT) que, apesar de ser um Centro vinculado ao Instituto Brasileiro do Meio Ambiente e dos Recursos Naturais Renováveis (IBAMA), em seu quadro de servidores havia representantes das Populações Tradicionais. Com a publicação da Instrução Normativa n $n^{\circ}$ 03/ICMBio, em 2007, a criação de Resex passam a ser conduzidas por diretrizes, normas e procedimentos específicos. Desse modo, as solicitações formais para a criação de Resex devem ser prerrogativa das populações tradicionais ou sua representação. De acordo com as diretrizes para a criação das Resex, deve ser assegurada, primordialmente, a conservação da biodiversidade e a sustentabilidade ambiental, bem como 
a participação ativa das populações tradicionais, de modo que sejam reconhecidos e valorizados os seus saberes, seus territórios e formas de organização social. Porém, a integração dos objetivos relativos à conservação da biodiversidade e aos direitos das populações tradicionais é uma tarefa desafiadora, considerando-se as diferentes clivagens no ambientalismo brasileiro (Acselrad, 2010). Sendo assim, em que medida podemos afirmar que, no contexto marinho-costeiro, os pescadores artesanais têm sido protagonistas nas demandas de criação das Resex Mar?

Nesse sentido, o presente artigo tem o intuito de refletir sobre a etapa pré-implementação das Resex a partir da análise das representações sociais de pescadores artesanais sobre Reserva Extrativista. Considerando que as reservas extrativistas são o resultado de construtos sociais compartilhados entre os principais sujeitos implicados no processo de criação de territórios que protegem seus modos de vida e suas maneiras de reprodução sociocultural - tal qual o artigo 18 do SNUC -, o estudo das representações sociais nos oferece uma relevante abordagem para se compreender os conhecimentos compartilhados por esses sujeitos e seu protagonismo no processo desta política pública.

A pesquisa foi realizada no litoral centro-sul de Santa Catarina, onde há dois processos de criação de Reservas Extrativistas parcialmente sobrepostas ao território da Área de Proteção Ambiental da Baleia Franca (APA BF): Reserva Extrativista da Pesca Artesanal de Imbituba e Garopaba e Reserva Extrativista do Farol de Santa Marta.

Diante esses processos, chamou atenção o fato de existirem posicionamentos bem demarcados em relação às Resex no interior dos grupos de pescadores das diferentes localidades, configurando-se dois grupos antagônicos: os contrários à implantação da Resex no território; e os favoráveis. É importante mencionar que este comportamento social se repetiu em outros contextos de criação de Resex, a exemplo dos pescadores no sul da Bahia (Nicolau, 2006). $\mathrm{O}$ que nos chama a atenção é que, em princípio, a proposta de Resex, ao enquadrá-los na categoria de população tradicional, traria "benefícios" a todos os pescadores artesanais locais. Diante disso, com o intuito de apreender o conhecimento compartilhado por esses diferentes grupos de pescadores artesanais, buscamos aporte na teoria das representações sociais (Moscovici, 1982; Jodelet, 2001), procurando assim, aprofundar as respostas para as seguintes perguntas: Como compreendem esta política pública? Quais conhecimentos mobilizam para se posicionar em relação à Resex? Eles têm sido de fato sujeitos do processo?

O presente artigo está estruturado da seguinte forma: após uma breve descrição da área de estudo, abordamos a teoria das representações sociais, pontuando suas contribuições para a apreensão de conhecimentos compartilhados por grupos sociais. Em seguida, apresentamos a metodologia e técnicas utilizadas nesta pesquisa. Em um terceiro momento, realizamos uma caracterização do contexto no qual ocorrem as propostas das Resex Mar, trazendo à luz alguns dos conflitos e coalizões sociais que permearam os processos. Por fim, nos propomos a desvendar as representações sociais dos pescadores artesanais e refletir sobre os principais resultados.

\section{Area de estudo}

As duas propostas de criação das Resex se sobrepõem ao território marinho da APA BF. Somente as lagoas e suas respectivas áreas de marinha estão 
fora dos limites desta $\mathrm{UC}^{2}$. AAPA BF é uma UC de uso sustentável criada em 2000, situada no litoral centro-sul de Santa Catarina, e tem como objetivo principal

(...) proteger, em águas brasileiras, a baleia franca austral Eubalaena australis, ordenar e garantir o uso racional dos recursos naturais da região, ordenar a ocupação e utilização do solo e das águas, ordenar o uso turístico e recreativo, as atividades de pesquisa e o tráfico local de embarcações e aeronaves" (Brasil, 2000b, Art.1).

A APA BF dispõe de uma área de 156.100 ha, sendo a sua maior porção marinha. Possui cerca de 130 quilômetros de extensão, abrangendo 9 municípios e formando um verdadeiro mosaico de ambientes. Para a gestão deste complexo território a equipe da APA BF divide geopoliticamente sua extensão em três núcleos, a saber: núcleos norte, sul e central. É no núcleo Central que fica sua sede administrativa, local onde ocorre maior capilaridade dos seus processos administrativos. Segue abaixo o limite territorial da APA BF e das propostas das Resex.

As propostas de criação das Resex abrangem áreas marinhas e lagunares dos municípios de Garopaba, Imbituba, Laguna e Jaguaruna., e por isto, o foco deste estudo está nesta porção do território da APA BF. A área de abrangência da proposta da Resex do Cabo de Santa Marta tem como limite norte a Ponta do Gí, localizada no município de Laguna, SC, e como limite sul, a Barra do Rio Urussanga, município de Jaguaruna, SC, em sua porção leste segue as linhas limítrofes da APA BF, aproximadamente cinco milhas, incluindo ainda as Lagoas do Camacho e de Santa Marta. A área proposta para criação da Resex envolve exclusivamente áreas aquáticas, dunas e sítios arqueológicos para não incorrer em desapropriação (Socioambiental, 2005).

A área marinha da proposta da Resex da Pesca Artesanal de Imbituba e Garopaba também coincide com o território marinho da APA BF, e o território lagunar inclui o espelho d'água das Lagoas de Garopaba, Ibiraquera e lagoas menores adjacentes, os quais estão quase integralmente fora dos limites da APA BF. Essas lagoas integram um complexo sistema lagunar costeiro, que se destaca do ponto de vista da diversidade biológica e cultural.

Os municípios de Garopaba e Imbituba, concentram $8,8 \%$ das embarcações pesqueiras artesanais catarinense, utilizadas para a pesca oceânica e estuarina. Junto à pesca marinha realizada nesses municípios, ocorre a pesca estuarina e lagunar, realizada no Complexo Lagunar Catarinense e nas lagoas, como nas Lagoas de Ibiraquera e Garopaba. (SEAP/PROZEE/IBAMA, 2006 apud Capelesso, 2010). O município de Laguna se destaca na atividade da pesca artesanal, concentrando $24,6 \%$ das embarcações artesanais cadastradas em Santa Catarina, o maior número do Estado. Além da forte expressão da pesca artesanal, a pesca industrial também encontra papel de destaque, apesar de ocorrer principalmente por frotas de outras localidades, como Itajaí e Rio Grande do Sul. No município de Jaguaruna, apesar da presença da pesca artesanal, a principal fonte econômica do município é a agropecuária. Dentre os principais cultivos estão: o arroz irrigado, a mandioca, a melancia, o fumo e o leite. No setor industrial a atividade de mineração ocupa posição importante. Em 1997, esta atividade representava $70 \%$ da arrecadação do ICMS local no setor, tendo sido uma única empresa, a Cysy

\footnotetext{
${ }^{2}$ Somente a Lagoa de Ibiraquera possui um pequeno trecho - incluindo a sua barra - nos limites da APA BF.
} 

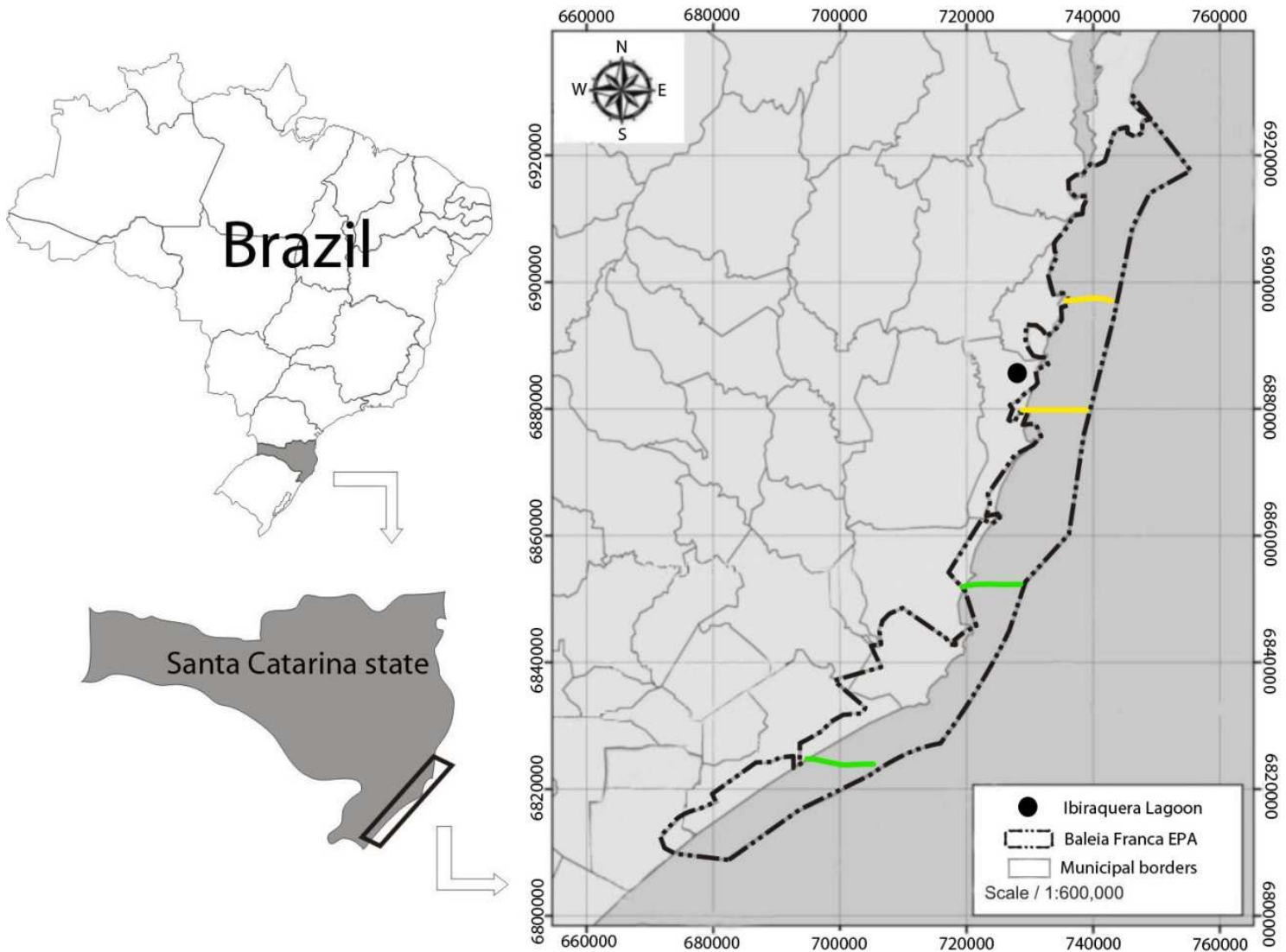

FIGURA 1 - Limites da APA da Baleia Franca e as propostas das Resex. Em amarelo o limite norte-sul da Resex da Pesca Artesanal de Imbituba e Garopaba e em verde o limite norte-sul da Resex do Cabo de Santa Marta.

FONTE: Adaptado de Gerhardinger (2014).

Mineradora, responsável por $25 \%$ da arrecadação total do tributo no município na mesma data (Socioambiental, 2005). A mineração de conchas calcárias desenvolvida pela Cysy é uma atividade conflitante com os objetivos da APA BF, e foi alvo de diversos embates entre os atores sociais do território ${ }^{3}$.

\section{A contribuição da Teoria das Representações Sociais}

A busca de compreensão do posicionamento dos pescadores artesanais em relação às Resex se baseia na teoria das representações sociais (Jodelet, 2001; 2005; Moscovici, 1982). Esta teoria favorece a apreensão do conhecimento compartilhado pelos grupos, suas motivações, crenças e atitudes, que por sua vez, embasam suas estratégias e orientam (de maneira complexa e às vezes contraditória) suas ações. Ao oferecer um olhar centrado na relação

\footnotetext{
${ }^{3}$ Ver Albuquerque (2009).
} 
entre o sujeito e a realidade social, ela supera a visão que reduz um ao outro. Dessa forma, a teoria das representações sociais "É uma teoria cientifica sobre os processos através dos quais os individuos em interação social constroem explicações sobre objetos sociais" (Wachelke \& Camargo, 2007, p. 379).

Fruto da tese de doutorado de Sèrge Moscovici La psychanalyse: Sonimage et sonpublic, publicada em 1961, a teoria das representações sociais permaneceu pouco conhecida durante muitos anos, sendo disseminada pela antropóloga Denise Jodelet a partir da década de 1980. Existem, todavia, várias propostas de abordagem analítica do fenômeno da representação social. Neste artigo foi assumida a perspectiva elaborada originalmente por Moscovici (1982). O fenômeno das representações sociais é entendido, em linhas gerais, como uma forma particular de conhecimento compartilhado por grupo, uma maneira de tornar 'próximo' e 'familiar' algo não familiar, estranho e carente de compreensão. Segundo Moscovici (1982), o fenômeno das representações sociais só se torna possível com o avanço da ciência dos sistemas comunicacionais. Esta última possibilita maior interatividade entre os diversos grupos sociais, de modo que o conhecimento individual e coletivo passa a ser construído de forma mais autônoma e plural.

$\mathrm{Na}$ abordagem de Moscovici, as representações sociais possuem três dimensões essenciais: informação, atitude e campo. O processo de formação das representações sociais é analisado a partir das relações estabelecidas entre o nível de conhecimento (a organização dos conhecimentos que um grupo dispõe a respeito de determinado objeto social), a atitude (ou tomada de posição, positiva ou negativa, em relação ao objeto), e o campo de representação, ou seja, a estrutura das relações entre conhecimentos (Camargo et al., 2007).

Posteriormente, a abordagem dinâmica trouxe diversas contribuições aos estudos iniciados por Moscovici sobre os processos de objetificação ${ }^{4}$ e ancoragem das representações sociais. O processo de ancoragem possibilita a incorporação de algo não-familiar e problemático em nossa rede de categorias conceituais pré-existentes. Nesse sentido, ancorar é classificar, rotular e nomear; consiste em dar sentido a algo por meio de uma rede de conceitos e significações, tornando assim possível a construção do universo consensual. O segundo processo é a objetificação, que dá concretude ao abstrato, ou seja, transforma o conceito em imagem ou coisa, reduzindo a sua complexidade. Cada representação social possui determinado grau de objetificação, de acordo com o nível de materialidade construído pelo grupo, e seu ponto culminante se dá quando a diferença entre imagem e realidade é eliminada (Doise, 2001; Moscovici, 1982).

A abordagem estrutural (Abric, 2003; Sá, 1996) é a mais recente, e compreende as representações sociais como um sistema de interpretação da realidade que guia a ação dos grupos sociais. $\mathrm{O}$ foco desta abordagem está no estudo do processo de objetificação. Nessa abordagem as relações entre representação social e práticas sociais são centrais. "São as práticas sociais que determinam as representações ou o inverso? Ou as duas são indissociavelmente ligadas e interdependentes?" (Abric, 1994 apud Sá, 1996, p. 88). Mesmo considerando o papel fundamental das representações no deline-

\footnotetext{
${ }^{4}$ Os estudos atuais sobre objetificaçao equivalem aos estudos iniciais de Moscovici sobre "campo" da representação, e têm sido aprofundados principalmente pela abordagem estrutural (Camargo et al., 2007).
} 
amento das práticas sociais, há que se considerar a relevância do contexto na criação e transformação das representações sociais. As condições concretas de reprodução da vida social e o contexto social mantêm uma relação dialógica com o processo de formação de representações sociais.

Diante as reflexões acima, com a chegada das propostas das Resex no litoral centro-sul de Santa Catarina, novos atores sociais e um novo universo semântico aportam no cotidiano dos pescadores artesanais, os quais, durante o percurso, vão, ressignificando as Reservas Extrativistas, elaborando teorias "leigas" que embasam, e ao mesmo tempo justificam, seus diferentes posicionamentos e práticas sociais. Desse modo, a compreensão dessas representações sociais sobre Reserva Extrativista se mostra valiosa para desvelar em que medida tais pescadores são protagonistas dos processos de criação das Resex no litoral sul de Santa Catarina. Além disso, o estudo das representações sociais pode nos oferecer elementos relevantes para se refletir sobre a forma como esta política pública tem sido construída localmente na zona costeira.

\section{Metodologia}

A complexidade inerente às teorias do senso comum transparece nas distintas associações de técnicas de recolha e análise de dados adotadas nas investigações realizadas no âmbito da Teoria das Representações Sociais (Soares, 2005). Nesta pesquisa qualitativa (Quivy \& Campehoudt, 1992) foram realizadas, durante os meses de setembro de 2011 a fevereiro de 2012, 60 entrevistas com pescadores artesanais, dos quais 30 são pescadores do contexto da proposta da Resex do Cabo de Santa
Marta e os outros 30 são pescadores do território proposto para a Resex da Pesca Artesanal de Imbituba e Garopaba. A seleção dos entrevistados foi feita de modo que no total, se configurassem dois grupos: $50 \%$ a favor e $50 \%$ contra às Resex, em cada contexto, abrangendo tanto os pescadores lagunares, quanto aqueles que exercem suas atividades em ambiente marinho. Embora a pesquisa se insira em uma abordagem qualitativa, a análise textual das entrevistas realizadas contou com os aportes do programa informático Alceste (Análise Lexical Contextual de um Conjunto de Segmentos de Texto). O uso do software Alceste transcende a dicotomia qualitativa/quantitativa, de modo a empreender técnicas quantitativas de agrupamentos de palavras que, por sua vez associa estes agrupamentos a segmentos de texto, também denominados Unidades de Contexto Elementar (UCE). A importância que a palavra possui no âmbito de determinada classe lexical é medida por intermédio de sua frequência de aparição a partir do teste de qui-quadrado $\left(\mathrm{x}^{2}\right)$. O Alceste apreende os dados de pesquisa a partir da análise de um conjunto de vocábulos principais, compartilhado entre os entrevistados, apontando para respectivas significações de acordo com o contexto em que estão inseridos. Assim, a análise dos significados apreendidos no universo lexical oriundos das entrevistas irá se sobrepor a um contexto segundo o qual estão inseridos.

Este software veio a contribuir para uma melhor compreensão da comunicação social a partir de uma análise da linguagem das representações sociais que organizam e dão forma ao pensamento e ao conhecimento social. Elaborado no final da década de 70, por Max Reinert, consiste em um "método de estatística textual, que tem como principal objetivo a identificação da organização tópica do discurso 
e não as diferenças estatísticas entre os textos que compõem um corpus." (Soares, 2005, p. 549).

A utilização do Alceste demanda a preparação do material segundo algumas regras. As entrevistas foram transcritas na íntegra e identificadas por meio da variável atitude (favorável ou contrária à Resex). Nesse sentido, cada resposta à entrevista composta de uma questão aberta foi assumida como uma unidade de contexto inicial (UCI), que em seu conjunto compõe o corpus de análise. Como aponta Camargo (2005), o corpus adequado à análise do Alceste deve ser constituído de no mínimo vinte Unidades de Contextos Iniciais (UCI), além de ter num conjunto textual centrado em um tema. O material textual deve ser monotemático, pois a análise de textos sobre vários itens previamente estruturados ou diversos temas resulta na reprodução da estruturação prévia dos mesmos, comprometendo toda a análise (Soares, 2005, p. 530). Nesta pesquisa, a questão aberta direcionada aos pescadores artesanais foi a seguinte: Questão aberta: Para você o que é uma Reserva Extrativista? Por que uma reserva Resex na região?

Com o intuito de compreender a maneira com que a política "Reserva Extrativista" aporta no território costeiro centro-sul de Santa Catarina, as representações sociais sobre "reserva extrativista" são relativas ao total de pescadores entrevistados, não havendo diferenciação por contexto de cada Resex. Os resultados foram obtidos por meio do método de contraste com base na variável atitude, que consiste em induzir o software, a partir de linhas de comando, a processar as respostas de todos os pescadores em dois grupos: os 30 pescadores a favor e os 30 pescadores contrários às duas Resex, de modo a apreender os vocabulários e as unidades de contexto elementar (UCE) características de cada grupo. Inicialmente, o programa faz o reconhecimento das unidades de contexto iniciais (UCI), que coincidiu com cada entrevista, para em seguida, realizar a divisão de cada UCI em UCEs, que na maior parte das vezes são constituídas por três linhas de texto, a depender do tamanho do corpus. Nessa etapa o programa agrupa as ocorrências das palavras em função de suas raízes e realiza o cálculo de frequência dessas formas reduzidas. A etapa seguinte consiste na classificação das UCE em função de seus respectivos vocabulários e a repartição do conjunto das UCE em função da frequência das formas reduzidas que elas apresentam (Teixeira et al., 2002; Camargo, 2005).

Por fim, com o intuito de compreender o contexto e as interações entre os grupos sociais, foram realizadas entrevistas semiestruturadas com os 60 pescadores artesanais, além de 15 entrevistas com instituições governamentais e não governamentais ligadas à pesca e à conservação ambiental no território de estudo. Ademais, os autores foram moradores do território, o que facilitou a observação do cotidiano das comunidades, além de atuarem como pesquisadores e/ou consultores ${ }^{5}$ em diferentes espaços públicos relacionados à gestão do território, a exemplo do Conselho Comunitário de Ibiraquera, Fórum da Agenda 21 Local da Lagoa de Ibiraquera, Conselho Consultivo da APA BF, entre outros. A análise documental também se mostrou de grande relevância para a pesquisa, de modo que

${ }^{5}$ Um dos autores foi consultor PNUD/ICMBio para a construção de um Plano de Capacitação dos Pescadores Artesanais da APA BF (2008 a 2010) e consultor do CEADS/MPA no território sul da APA BF com o objetivo de subsidiar um Plano de Gestão da Pesca Artesanal (2011 a 2012 ). 
foram analisados os dois processos administrativos de criação das Resex.

\section{Contextualizando os processos de criação das Reservas Extrativistas no litoral de Santa Catarina}

\subsection{A Resex do Cabo de Santa Marta}

A proposta de criação da Resex foi liderada pelo presidente de uma Organização não governamental ambientalista sediada no Farol de Santa Marta, a ONG Rasgamar, que juntamente com a Associação de Pescadores do Farol de Santa Marta (APAFa), solicitou, em 2002, a criação da Resex ${ }^{6}$. O quadro 1 abaixo caracteriza os principais acontecimentos no território, conforme as etapas do processo de criação da Resex, previstas na Instrução Normativa/ ICMBio $n^{\circ} 03 / 2007$, bem como os principais grupos envolvidos e seus posicionamentos:

Os principais conflitos do processo de criação desta Resex são relacionados ao contexto da Lagoa do Camacho. A maioria dos pescadores lagunares se posicionou contra à inclusão dos seus territórios de pesca na proposta da Resex. Este posicionamento está relacionado a outros dois conflitos presentes

QUADRO 1 - O Passo-a-passo no processo de criação da Resex do Cabo de Santa Marta.

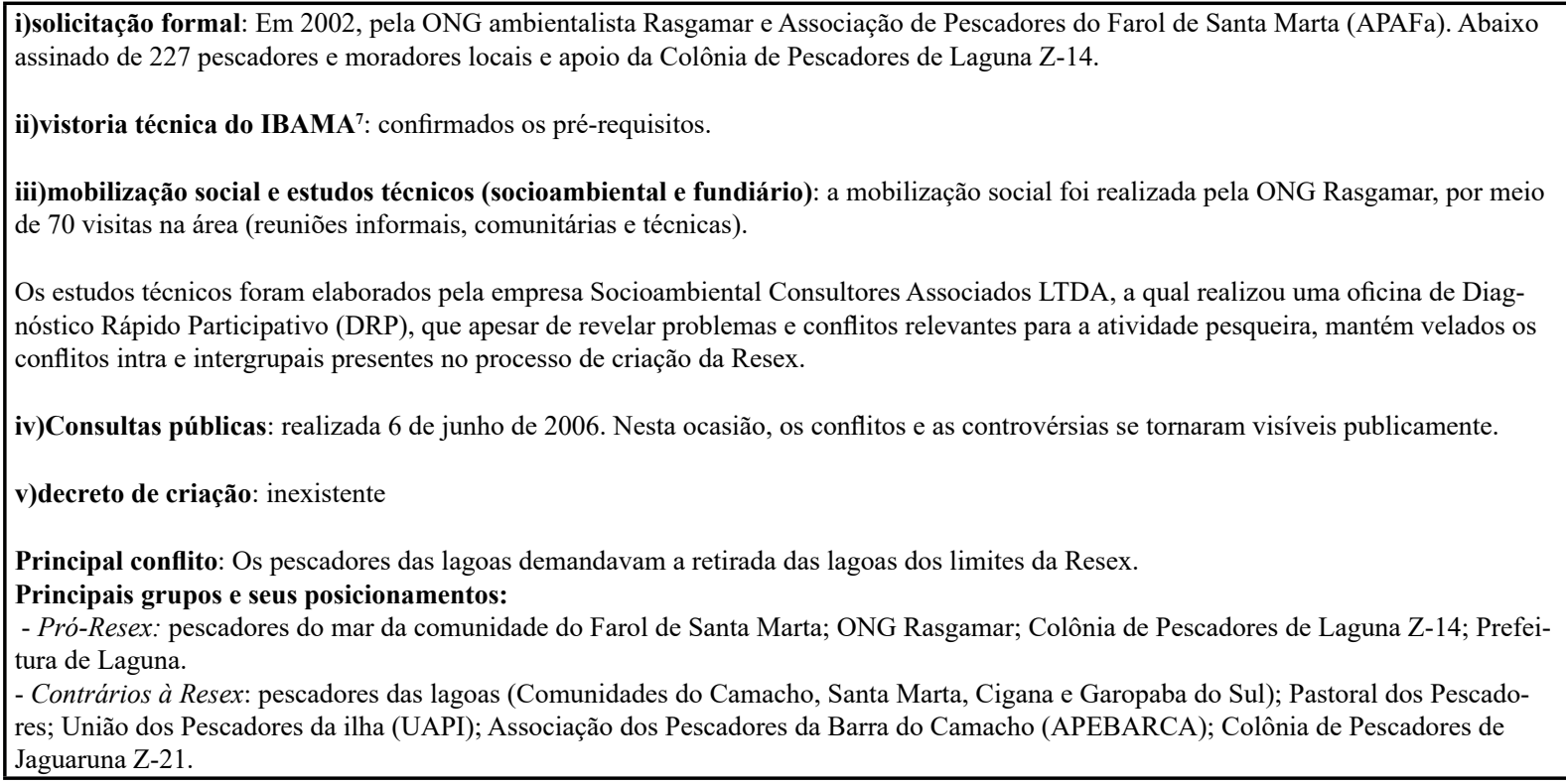

FONTE: Vivacqua (2018).

\footnotetext{
${ }^{6}$ De acordo com a comunicação pessoal do presidente da ONG Rasgamar, a ideia de Reserva Extrativista para o território em questão, nasceu a partir de uma visita à Reserva Extrativista do Corumbau, localizada no extremo sul baiano, em meio à data comemorativa de sua criação. Naquela ocasião, a liderança conheceu o então coordenador responsável pela criação de Resex, da extinta Diretoria Socioambiental do IBAMA.

${ }^{7} \mathrm{Na}$ época a gestão das Unidades de Conservação ainda estava sob responsabilidade do IBAMA.
} 
neste território: (i) $\mathrm{O}$ conflito entre pescadores do Complexo Lagunar em relação às regras para a pesca do camarão-rosa (Penaeus paulensis e $P$. brasiliensis), o qual se desdobra no Acordo de Pesca do Complexo Lagunar; (ii) Os conflitos gerados pela atividade de mineração de conchas calcárias na barra da lagoa do Camacho.

No primeiro caso, o processo foi conduzido pelo Centro de Pesquisa e Gestão dos Recursos Pesqueiros Lagunares e Estuarinos (CEPERG/ IBAMA) em parceria com o Conselho Pastoral dos Pescadores (CPP), por cerca de 3 anos, e contou com inúmeras reuniões nas comunidades locais, propondo, além da normatização específica para a pesca do camarão, a criação de um arranjo de gestão comunitária do Complexo Lagunar - o Conselho de Representantes das Comunidades Pesqueiras. Apesar das possíveis sinergias deste Acordo e a proposta da Resex, os dois processos foram conduzidos de forma paralela. $\mathrm{Na}$ fala de muitas lideranças e pescadores, a criação da Resex representaria uma intervenção de outros atores externos, como a APA BF e a ONG Rasgamar, na gestão do complexo lagunar, deslegitimando o que foi construído durante o Acordo de Pesca.

$\mathrm{O}$ segundo conflito diz respeito à abertura da barra da Lagoa do Camacho. Neste conflito estão envolvidos também a APA BF, a Fundação Estadual do Meio Ambiente (FATMA), Ministério Público Federal, e a Cysy Mineradora Ltda. Autorizada a minerar conchas calcárias na lagoa, a Cysy mantinha, em troca, a barra da lagoa aberta, atendendo assim a uma antiga demanda dos pescadores (Albuquerque, 2009). Grande parte dos pescadores apoia a presença da empresa mineradora, em troca da abertura da barra pela empresa - uma atividade que se insere na esfera de competência do Poder Público. Para esses pescadores, a atividade de extração de conchas não representa risco para a saúde da lagoa. Além disso, a manutenção da barra aberta garante a melhoria da qualidade ambiental da lagoa, viabilizando a atividade pesqueira, enquanto mantê-la fechada acaba colocando em risco a subsistência das famílias de pescadores.

Coube à APA BF avaliar a anuência do processo, ficando o licenciamento a cargo da Fundação do Meio Ambiente. A chefia da APA BF e seu Conselho Gestor se posicionaram contrários a esta atividade, $\mathrm{o}$ que contribuiu para gerar, e também cristalizar, uma visão negativa dos pescadores em relação à APA BF.

Desse modo, durante o processo de mobilização social para a criação da Resex, os pescadores das lagoas mantiveram uma relação de "desconfiança" em relação à proposta, receosos com as possíveis restrições que a Resex poderia trazer para as suas atividades. A ONG Rasgamar, na época representante no Conselho da APA BF, era confundida localmente como porta-voz da APA BF. Ademais, durante as reuniões de mobilização para a criação da Resex, eram tratados outros temas capitaneados pela ONG Rasgamar, a exemplo do projeto de Tombamento do Patrimônio Arqueológico e Natural da região, gerando confusões a respeito das categorias de UCs.

É importante revelar que as narrativas oriundas tanto dos grupos de pescadores contrários quanto dos pescadores favoráveis à criação da Resex apontaram para um desconhecimento acerca dos limites territoriais que abrangiam a proposta.

O delineamento de dois grupos com posicionamentos antagônicos relativos à criação da Resex ficou mais explícito após as audiências públicas. Aos poucos, esses grupos foram se cristalizando no interior dessas comunidades: os pescadores “a favor" - liderados pela ONG Rasgamar; e os 
pescadores "contra", os quais têm sido liderados pela Pastoral dos Pescadores. Na mesma época do processo de criação da Resex, esta Pastoral apoiou a criação da União das Associações de Pescadores da Ilha (UAPI), que juntamente com a Colônia de Pescadores de Jaguaruna e a Associação de Pescadores da Barra do Camacho (APEBARCA), lideraram o grupo contrário à Resex.

\subsection{A Resex da Pesca Artesanal de Imbituba e Garopaba}

A proposta de criação da Resex da Pesca Artesanal de Imbituba e Garopaba foi liderada pelo Fórum da Agenda 21 Local da Lagoa de Ibiraquera, no município de Imbituba. Este Fórum foi criado no ano 2002, e resultou de uma parceria firmada entre associações locais sediadas no entorno da Lagoa e o Núcleo Interdisciplinar de Meio Ambiente e Desenvolvimento da Universidade Federal de Santa Catarina (NMD/UFSC). Desde a sua instituição, se configura como um espaço público de debates e intervenções relacionadas à compreensão e ao enfrentamento de problemas e conflitos de apropriação e de gestão dos recursos naturais da lagoa e do seu entorno. As interações interinstitucionais transescalares neste Fórum possibilitaram o contato dos pescadores artesanais com a temática das unidades de conservação (Adriano, 2011). Além disso, houve momentos de interações entre a ONG Rasgamar e alguns pescadores do Farol de Santa Marta com integrantes do Fórum ligados à pesca, o que veio a potencializar o pleito pela criação de uma Resex no território.

Diversos pescadores artesanais e lideranças da pesca no entorno da Lagoa de Ibiraquera compar- tilham uma visão estigmatizada do Fórum, o qual é visto como propriedade de um "grupinho". Um integrante do Fórum bastante mencionado pelos pescadores é a APA BF, na figura da sua chefe à época. A ASPECI tem sido uma das grandes parceiras da APA BF, participando do Conselho Gestor (CONAPA BF) desde a sua criação. Por outro lado, as colônias de pesca sempre estiveram ausentes, tanto do Fórum quanto do CONAPA BF. Nesse sentido, no olhar dos "outros", ou seja, aqueles pescadores e lideranças locais que não participam do Fórum, ele não é visto como um espaço público democrático, capaz de fazer jus ao pluralismo de interesses e instituições sediadas na área. Ele tem sido, antes, associado a um agrupamento de pessoas - ou "amigos" - que compartilham interesses comuns. Segue abaixo uma síntese do processo de criação desta Resex.

Como observado acima, o processo de criação da Resex é um desdobramento dos debates e atuações do Fórum da Agenda 21. No entanto, a chegada da proposta da Resex no território ocorre no momento em que há um desgaste da imagem do Fórum diante a comunidade local, devido a um conflito envolvendo um importante núcleo familiar de pescadores artesanais ${ }^{9}$. Esses mesmos pescadores, incentivados pelo Fórum, criaram a ASPECI, a qual foi protagonista no pleito pela Resex. Além disso, vale mencionar que do ponto de vista sociopolítico, o Fórum representava uma coalizão de atores governamentais e parceiros locais, porta-vozes da conservação ambiental, ganhando destaque a APA BF. Vale mencionar que os pescadores artesanais de Garopaba e Imbituba configuram grupos heterogêneos. Na perspectiva daqueles pescadores e lideranças locais que não participam do Fórum, o mesmo não é visto como 
i)solicitação formal: Em 2005, pelo Fórum da Agenda 21 Local da Lagoa de Ibiraquera e a Associação de Pescadores da Barra de Ibiraquera (ASPECI) - criada no âmbito do Fórum em 2005.

ii)vistoria técnica do IBAMA: realizada em 2006, quando foi confirmada a presença de população tradicional na área, organizada e a relevância ecológica;

iii)mobilização social e realização de estudos técnicos (socioambiental e fundiário): a mobilização social foi coordenada pelo Grupo de Trabalho Resex (GT Resex) do Fórum da Agenda 21 Local da Lagoa de Ibiraquera. Os estudos biológicos foram realizados por técnicos do IBAMA, e os diagnósticos socioeconômico e fundiário ficaram sob responsabilidade de dois consultores do MMA.

O GT Resex foi o principal espaço de diálogo para a criação da Resex, contudo, o poder público municipal e as colônias de pescadores de Imbituba e Garopaba permaneceram ausentes do processo. No total foram realizadas 53 reuniões abertas.

iv) Consultas públicas: Realizadas em 19 e 20 de dezembro de 2007. O grupo majoritário posicionava-se contra a Resex, exibindo o lema "Natureza Sim, Resex Não" Principal argumento deste grupo: a Resex iria impactar o desenvolvimento econômico dos municípios.

v)decreto de criação: inexistente

Principal conflito: inclusão de áreas terrestres, especificamente as "áreas de marinha” nos limites da Resex.

Principais grupos e seus posicionamentos:

- Pró-Resex: Fórum da Agenda 21, GT Resex (Associação de Pescadores da Comunidade de Ibiraquera, Associação de Pescadores de Garopaba, APA da Baleia Franca, Centro Comunitário de Ibiraquera, Fundação Gaia)

- Contrários à Resex: Pescadores artesanais, principalmente aqueles apoiadores das Colônias de Pescadores, empresários locais, governo estadual.

FONTE: Vivacqua (2018).

um espaço público democrático, capaz de fazer jus ao pluralismo de interesses e instituições sediadas na área. Ele tem sido, antes, associado a um agrupamento de pessoas - ou "amigos" que compartilham interesses comuns. Diante a ausência do poder público municipal no Fórum, a APA BF se configurou como o principal ator social representante do Estado, principalmente na figura de sua chefia na época. Nesse contexto, se configuram duas coalizões em torno do processo de criação da Resex. A ASPECI tem sido uma das grandes parceiras da APA BF, participando do CONAPA
BF desde a sua criação. Por outro lado, as Colônias de Pescadores sempre estiveram ausentes tanto do Fórum quanto do CONAPA BF.

O poder público municipal e as Colônias de Pescadores de Imbituba e Garopaba e empresários locais permaneceram ausentes dos espaços coletivos de diálogo de construção da proposta conduzidos pelo GT Resex do Fórum da Agenda 21 Local da Lagoa de Ibiraquera. Aos poucos, o poder público municipal de Imbituba e Garopaba começou a se pronunciar de modo contrário à Resex. Em maio e junho de 2007 a Câmara de Vereadores de Imbituba e também a de Garopaba realizaram duas audiências

\footnotetext{
${ }^{8}$ Esse mesmo lema foi utilizado na campanha contrária no processo de criação das Resex de Canavieiras no contexto da zona costeira da Bahia.

${ }^{9}$ Este conflito ficou conhecido localmente como o Mensalão da Praia Vermelha. Cf. Adriano (2011).
} 
públicas com o intuito de se discutir a proposta da Resex. Após as audiências os posicionamentos contrários transpuseram o âmbito privado e passaram a abranger os espaços públicos, seja por meio uso de adesivos contra a Resex, entrevistas nas rádios e jornais locais, ou moções de repúdio à Resex. A proposta da Resex levada à consulta pública incluiu, em sua porção terrestre, somente alguns "terrenos de marinha" sob jurisdição da União, os quais, porém, foram retiradas da proposta final. Durante as audiências e, posteriormente na fase de ajuste da proposta, se revelou uma coalizão pouco visível durante todo o processo, a qual, porém, teve grande poder de negociação. A Fundação Gaia, mentora do projeto ambiental Gaia Village, se posicionou favoravelmente à criação da Resex com a condição da exclusão dos terrenos de marinha propostos inicialmente. $\mathrm{O}$ projeto é desenvolvido na fazenda dos empresários da família Werlang, e possui a concessão de uso dos terrenos de marinha que fazem limites com a propriedade na praia do Ouvidor em Garopaba. Os proprietários da fazenda mantêm uma cerca no local, trazendo restrições de acesso ao rancho de pesca situado no terreno de marinha. Contudo, a proposta da Fundação Gaia encontrou apoio no âmbito de diversas organizações ambientalistas nos níveis local, nacional e internacional, inclusive da APA BF, que se posicionou favorável no Conselho Municipal de Meio Ambiente de Garopaba.

\section{Desvendando as representações sociais}

Com a chegada das propostas das Resex novos atores sociais e um novo universo semântico aportam no cotidiano das populações locais, as quais, durante o percurso vão, estrategicamente, formando novas alianças e/ou fortalecendo antigas. O estranhamento inicial dos pescadores artesanais ao fenômeno da Resex, aos poucos, dá lugar a algo familiar, possibilitando a construção de um conhecimento compartilhado sobre Reserva Extrativista. A seguir serão apresentadas as representações sociais dos pescadores artesanais sobre reserva extrativista, tanto daqueles pescadores que se posicionaram favoráveis, quanto os contrários à criação das Resex.

\subsection{Grupo de pescadores favoráveis à criação das Resex}

Para os pescadores favoráveis à criação das Resex, em sua maioria pescadores do território marinho, a reserva é um mecanismo para afastar os barcos industriais para fora das cinco milhas náuticas da costa, reservando essa área exclusivamente para os barcos artesanais. Ganham destaque, conforme a Tabela 1, as palavras: área, artesanal, barco, industrial, milha, peixe, rede.

TABELA 1 - Palavras associadas significativamente ao grupo de pescadores favoráveis às Resex.

\begin{tabular}{ccc}
\hline Palavra & Frequência & $\mathbf{X}^{\mathbf{2}}$ \\
\hline Área & 43 & 4.62 \\
Artesanal & 26 & 21.10 \\
Barco & 28 & 10.89 \\
Costa & 17 & 7.09 \\
Governo & 11 & 6.19 \\
Industrial & 23 & 21.04 \\
Milha & 32 & 10.08 \\
Pedra & 15 & 5.05 \\
Peixe & 47 & 9.35 \\
Rede & 42 & 5.37 \\
Respeitar & 10 & 5.07 \\
Tirar & 28 & 6.32 \\
\hline
\end{tabular}


Seguem abaixo algumas UCE representativas desse grupo:

Essa reserva é pras indústria pesqueira respeitar o nosso, a nossa costa, né, pra eles pescar mais afastado, deixar a costa pra nós. Não nós deixar a costa pra eles, porque nós não temo embarcação pra ir muito longe.

E reserva no nosso entendimento é isso aí, vai ser botado o que? Malha de rede, quantia de rede, área que pode pescar, limitada, né, outras já não pode. O meu entendimento é assim, pelo menos foi o que a gente entendeu nas reunião que teve.

Para aqueles pescadores favoráveis, a criação da Resex representa um processo de gestão dos recursos pesqueiros, privilegiando as demandas da pesca artesanal.

Os conflitos e problemas que ocorrem nas pescarias na laje do Campo Bom, importante pesqueiro no contexto da Resex do Cabo de Santa Marta, também ganham destaque nas falas dos pescadores, que veem a Resex como uma possibilidade de fazer valer os acordos prévios relativos ao uso da laje do Campo Bom:

Esse ano não deu peixe lá na laje. Eu quase não fui lá, e aquela turma que tem um monte de rede, de gente rica, eles chegam lá e jogam em cima da pedra, o peixe vai malhando, vai apodrecendo.

A comunidade do Farol de Santa Marta vem passando por transformações socioculturais relacionadas à pesca, as quais trazem novos contornos à identidade do pescador artesanal local. As pescarias outrora realizadas com canoas de Garapuvu foram dando lugar a embarcações de maior porte e com motores mais potentes, mais aptas a enfrentar o "mar grosso". Em meio a essas transformações, foram sendo construídos ranchos ou galpões de pesca mais espaçosos para abrigar as embarcações pesqueiras. Os novos galpões e as artes de pesca vêm atribuindo novos significados ao "ser pescador do Farol". Essa transição vem se acentuando e é percebida pelos pescadores há cerca de 10 anos, com a venda de galpões e parelhas completas para turistas e empresários. Segundo os pescadores, a maioria da frota de grandes embarcações é dos de "fora", ou seja, empresários e turistas. Dessa maneira, a pesca realizada na praia do Cardoso vem se transformando gradativamente em uma pesca mais "agressiva". Dotados de recursos necessários à compra de embarcações de maior porte e de redes que acentuam o esforço de pesca, além do uso de tecnologias avançadas para identificação de cardumes, os empresários têm aumentado a competição entre os pescadores, os quais aos poucos vão perdendo autonomia e se transformando em "trabalhadores do mar" (Diegues, 1983).

A Laje do Campo Bom é um local de disputa territorial entre os pescadores do Farol, e destes com pescadores de outras comunidades. Para os pescadores do Farol, que possuem embarcações sem convés e de boca aberta, as embarcações de convés e casario, provenientes principalmente de Campos Verdes, Itapirubá e Garopaba são o principal motivo de conflitos de uso na Laje do Campo Bom. As embarcações de casario realizam a pesca da anchova no período noturno, que de acordo com os pescadores, não é um momento propício para esta pesca, pois a rede em contato com algas luminescentes produz fechos de luz que espantam os cardumes. Com a presença dos empresários proprietários de barcos no Farol, esses conflitos têm se adensado, sendo mais recorrentes conflitos entre os próprios pescadores do Farol: pescadores proprietários versus pescadores empregados. 
Já houve várias tentativas de implementar um acordo interno entre os pescadores do Farol, normatizando a pesca da anchova na Laje do Campo Bom. A principal regra desse acordo diz respeito à fixação do horário de saída das embarcações da praia do Cardoso, rumo à Laje. Conforme os depoimentos coletados, geralmente esta regra não tem funcionado mais que dois dias, gerando a necessidade de reuniões periódicas, visando reafirmar as regras do referido acordo - que versa também sobre a quantidade de fileiras de rede que cada embarcação pode utilizar. Desse modo, dentre os motivos que levaram os pescadores artesanais do Farol de Santa Marta a pleitear a criação de uma Resex Marinha está a necessidade de fazer valer o acordo referente à pesca na Laje do Campo Bom e, principalmente, afastar os barcos industriais da costa.

No entanto, as UCEs abaixo demonstram que o conhecimento adquirido e o posicionamento em relação às Resex foram tecidos em meio a controvérsias, dúvidas, medos e receios. Dois grupos defendendo os seus interesses e posicionamentos, e nessas relações cotidianas comunitárias, os pescadores artesanais foram construindo os seus respectivos posicionamentos, com base nas relações de confiança que cada um estabelece com quem comunica a informação.

Depois de feito não adianta mais, né, e a gente fica com receio. Eu até sou a favor, mas desde que deixe nós trabalhar toda vida, né, que faça as coisa certinho pra nós trabalhar toda vida. Porque uma reserva pra nós era bom, porque aí não ia poder mais entrar barco industrial, muita gente não ia poder usar.

Eu não sei, pra mim justificaram que a reserva deles não ia prejudicar nós em nada, quem pescava não ia ser prejudicado. Mas a gente já tá dando a entender que já tá mexendo com alguma coisa (...).

E o nosso medo era isso ai também, a reserva extrativista que podia daqui a pouco eles não deixar nós pescar aí também, muita gente falando isso. Mas falavam pra nós que não, que era só ter uma área deles ali pra proteger, que a embarcação com mais de dez tonelada não podia pescar ali na costa, os barco industrial tinha que ser cinco milha pra fora.

(...) bastante gente era contra. Não era contra, ficavam em dúvida, muita gente dizia: - Ah, não deixa fazer isso aí, tu vai ter que tirar tua casa daqui, vai ficar numa área de preservação e vais perder o terreno, depois tu fica na mão dos outro!

Em síntese, a representação social dos pescadores a favor da criação da Resex revela que esses pescadores acreditam que a Resex é uma política pública que irá empoderá-los diante do conflito com a pesca industrial, afastando os barcos industriais dos territórios da pesca artesanal. Nesse contexto, ganharam destaque os problemas vivenciados na pescaria da laje do Campo Bom, que tem se agravado com a venda dos ranchos de pesca para empresários no Farol de Santa Marta.

Apesar desse grupo se posicionar favorável à Resex, o estudo das representações sociais revelou incertezas nas falas desses pescadores, que mesmo apoiando a Resex, têm receios em relação às possíveis restrições que ela poderá impor ao uso dos recursos pesqueiros e à reprodução dos seus modos de vida. Nas UCEs acima se nota que esses pescadores não se encontram em uma posição de sujeitos do processo, mas sim enquanto objetos de uma política pública.

\subsection{Grupo de Pescadores que se posicionam contra a criação das Resex}

A tabela abaixo elucida as palavras mais representativas do grupo de pescadores que têm uma atitude contrária às Resex, com suas respectivas frequências e valor no teste do qui-quadrado. 
TABELA 2 - Palavras associadas significativamente ao grupo de pescadores contrários às Resex.

\begin{tabular}{ccc}
\hline Palavra & Freq. & $\boldsymbol{X}^{\mathbf{2}}$ \\
\hline Baleia Franca & 14 & 8.36 \\
Baleia & 12 & 10.08 \\
Camarão & 22 & 6.71 \\
Fizeram & 19 & 6.83 \\
Quilos & 12 & 6.69 \\
Vive & 20 & 5.27 \\
\hline
\end{tabular}

No contexto do grupo contrário à criação das Resex, se destacam diversos elementos na composição da representação social sobre Resex, os quais seguem abaixo.

\subsubsection{Reserva Extrativista: é coisa da APA da Baleia Franca!}

Os termos baleia franca e baleia possuem centralidade na representação social sobre a Reserva Extrativista. Contudo, o primeiro não se refere à espécie baleia franca (Eubalaena australis), e sim, à Área de Proteção Ambiental da Baleia Franca. Aos serem indagados sobre a Resex, os pescadores ancoram sua representação social em seu conhecimento prévio, em suas experiências práticas, associando a Resex à APA BF. A visão negativa que os pescadores expressam sobre a APA BF assume grande relevância para o posicionamento em relação à Resex. A UCE abaixo é representativa, pois ao serem indagados sobre a Resex, os pescadores se referem à atuação da $\mathrm{APA} \mathrm{BF}$ :

O que hoje você viu de resultado da Baleia Franca no estado de Santa Catarina? Se você fazer uma pesquisa dentro dos dois município aonde é a abrangência deles, não deu resultado em nada, em nenhum ponto.
Apesar da APA BF ser uma UC de Uso Sustentável, a mesma é compreendida pelos pescadores como um território delimitado para a conservação da baleia. Portanto, a incompreensão acerca dos objetivos da conservação gera desconfiança em relação à própria existência da APA BF. Além disso, são diversos os relatos em que pescadores denunciam os prejuízos ocasionados pela perda de redes de pesca devido ao contato com a baleia, que tem o seu período de visita ao litoral justamente durante a safra da anchova. Somados a isto, há uma confusão, na região de Garopaba e Imbituba, da APA BF com outras instituições que também levam o nome da baleia franca: o Projeto Baleia Franca e o Instituto Baleia Franca. A primeira, coordenada pela ONG Coalização Internacional da Vida Silvestre (IWC/ Brasil), tem sede na praia de Itapirubá, em Imbituba, e foi a instituição proponente da criação da APA BF; a segunda é uma ONG com sede na praia de Garopaba, que trabalha com educação ambiental e turismo embarcado de observação de baleia. Esta última não é "bem vista" pela maioria dos pescadores, que ressente ainda o fato de não terem incentivos governamentais para realizar o turismo embarcado.

Ai é diferente, vamos preservar o animal, mas já temos uma lei pra baleia. Ninguém trata da baleia, ninguém manda ela embora que ela vai mesmo, ninguém manda ela vim que ela vem mesmo.

Só que a Baleia Franca usa a baleia pra ganhar dinheiro, que ela bota vinte, trinta fotógrafo dentro de um bote e vai bater foto da baleia, mais cinquenta pila cada um.

Quando os pescadores associam a Resex à APA $\mathrm{BF}$, não o fazem somente no sentido de associar as duas categorias de UCs, mas principalmente como forma de justificar o posicionamento contrário à Resex. As relações de conflito e embates que esses pescadores artesanais sustentam com a APA BF, o 
conhecimento parcial acerca dos objetivos e papéis desempenhados por esta UC no território são alguns fatores que contribuem para esse posicionamento.

A visão que compartilham sobre a APABF enquanto uma instituição criada para a defesa do meio ambiente, seja por meio da proteção à baleia ou ao ordenamento do uso do solo, distante da realidade e necessidades concretas do pescador artesanal, é um argumento mobilizado para se posicionarem contra a Resex. Quando indagados acerca das diferenças entre a APA e a Resex, tais pescadores mobilizam diferentes discursos, oscilando entre uma fala que demonstra total desconhecimento e um discurso que conceitua a Resex como uma UC ainda mais restritiva do que uma APA, ou ainda, um território gerido pelos interesses da APA BF.

Na região do Camacho, município de Jaguaruna, muitos pescadores, tanto do mar quanto das lagoas, possuem laços de parentesco e reciprocidade com pescadores do Rio Grande do Sul, e associam a Resex também a outras UCs, como é o caso do Parque da Lagoa dos Peixes, no Rio Grande do Sul.

Se você fizer uma reserva que pega isso tudo aqui, ai cada um faz uma reserva, ai vamo fazer uma reserva pra nossa lagoa só pra nós. Tem uma lagoa lá no Rio Grande que não pode pescar, não pode nem mexer, e nós vivia. O que pesquemo de camarão lá quando era novo...

\subsubsection{Reserva Extrativista: defesa de um modo de vida do passado}

Para o grupo de pescadores que se posiciona contra a criação da Resex, ela significa a defesa de um modo de vida baseado no extrativismo, o qual já não representa a realidade do pescador artesanal da região. Desde a década de 1970, a pluriatividade baseada na pesca e agricultura vem progressivamente sendo substituída pelo binômio pesca-turismo, trazendo transformações na organização do espaço e nas relações socioculturais e econômicas nas comunidades.

\begin{abstract}
A Resex é uma reserva extrativista, é o lugar que vive só do extrativismo, de agricultura e pesca. Mas aqui na nossa região hoje a maioria, nós pesquemo e tudo, mas vivemo um pouco do aluguel de casa no verão.

(...) tem algum ainda que tem uma rocinha, mas a gente vive de aluguel de casa e pesca. O que mais dá o dinheiro é o camarão, mas chega mês de maio, junho, tem a tainha, dá pouco dinheiro, mas pesca.

(...) hoje já não plantemo mais, não temo mais nem onde plantar. E pra plantar, pra uma familia sobreviver, o espaço não pode ser pequeno, tem que ter ao menos quatro hectares de terra.
\end{abstract}

O apoio de muitos pescadores artesanais e moradores locais às propostas das Resex na ocasião das assinaturas dos abaixo-assinados se configurou em um momento em que a palavra Resex ainda carecia de significado para esses grupos sociais. Esse posicionamento foi se transformando, gradativamente, em intensa oposição. Como apresentar o conceito de Resex aos pescadores locais, que aprendem a partir da prática cotidiana, da observação e do aprender-fazendo? Esta questão nos parece desafiadora. A composição da imagem sobre Resex foi delineada a partir de elementos distantes da realidade vivenciada por esses pescadores. A apresentação de vídeos sobre Resex situadas em outros contextos parece ter sido um elemento relevante nessa composição, uma vez que tais imagens tornaram-se um ponto de referência para os pescadores conceberem a sua representação social e seus posicionamentos. Ao não se identificarem com a realidade apresentada nos vídeos, "casas de pau-a-pique, falta de energia elétrica, extrativismo só pra subsistência”, muitos 
pescadores passaram a questionar a coerência de se criar uma Resex em seus territórios. Diferentes interesses e atores sociais passaram a interagir no processo, antagonizando os grupos.

Nesse sentido, para esses pescadores a Resex significa um retorno ao passado, representado pela presença predominante do pescador-lavrador, e por isso, uma ameaça ao atual modo de vida dos pescadores artesanais, no qual os benefícios econômicos adquiridos com o turismo ganham importância crescente. Ademais, na percepção dos pescadores esse retorno ao passado se daria em nome da preservação ambiental, atendendo aos interesses das agências ambientais - a APA BF - que iriam impor limites ao uso e acesso aos recursos naturais.

\subsubsection{Reserva Extrativista: perda de autonomia dos pescadores artesanais na gestão de seu território}

Todo esse processo elucidado acima deságua na perda de autonomia dos pescadores artesanais, que ficariam à mercê dos interesses das agências ambientais:

Era uma das pior coisa. Se você vai fazer uma reserva extrativista o que é que vai acontecer? Se eu tiver errado você me corrija. Eu vou fazer uma reserva de Garopaba e Imbituba, o que que vai acontecer? Vai vim meia dúzia de gente mandar tudo isso aqui, e Garopaba e Imbituba tá sendo dois município em desenvolvimento.

(...) então tem que ser contra, tá entendendo? Eu sou contra um negócio pros de fora, mas pros nativo não sou contra.

(...) eles embargam muita coisa também, na lagoa, uma abertura de barra iam proibir, um rio, eles não iam deixar fazer nada disso aí.
Os pescadores não costumam associar a atuação das agências ambientais ao cumprimento da legislação, mas sim, com o atendimento a interesses diversos, pouco confiáveis e coerentes entre si. Os processos de manejo das barras das lagoas de Garopaba, Ibiraquera e do Camacho são emblemáticos nesse sentido, pois estão situadas dentro dos limites da APA BF. A perda de poder dos pescadores e instituições locais para fazer o manejo das barras, que é atribuição dos órgãos ambientais (estadual e federal), tem sido alvo de embates e conflitos na região ${ }^{10}$. Além disso, os pescadores artesanais têm vivido a constante ameaça de perda de suas terras e casas. Historicamente, boa parte dos pescadores têm as suas casas construídas à beira da lagoa, território que com a legislação ambiental passou a ser considerado Área de Preservação Permanente. Os diversos casos de embargo de construções nessas áreas e/ou áreas de marinha estão presentes no imaginário desses pescadores. Ademais, com a valorização da terra, os terrenos que ainda são de propriedade dos nativos têm assumido um novo significado, perdendo progressivamente o seu papel de meio de produção e passando a se constituir em uma espécie de reserva financeira ou poupança (Rosar, 2007). A população tradicional utiliza as terras para lavoura e criação de animais de pequeno porte. Ocorre, porém que, desde a década de 1970, com a intensificação do turismo, um novo uso tem sido atribuído à terra: construção de casas e pousadas para alugar no verão. Desse modo, figura entre eles o medo de perder suas terras, moradias e respectivas casas de aluguel. Sem conhecer os meandros da legislação, a Resex vem a exacerbar esse medo, colocando-o na ordem do dia!

\footnotetext{
${ }^{10}$ Cf. Adriano (2011) e Albuquerque (2009).
} 
Se for fazer uma reserva você não pode mais fazer uma casa que é uma reserva, não pode mais instalar uma luz que ali é uma reserva, não pode mais pescar na lagoa porque é uma reserva, você não pode mais vender um pedaço de terra porque é uma reserva.

Essas três dimensões sintetizam a representação social dos pescadores artesanais contrários à criação das Resex, a qual foi tecida em meio a um contexto sociopolítico marcado por disputas de poder entre as coalizões formadas. Uma proposta vinda "de fora", com interesse na preservação ambiental e na manutenção de um modo de vida que já foi ressignificado, implicando em regras restritivas ao uso do território impostas pelos órgãos ambientais - representado aqui principalmente pela APA BF. As experiências negativas que esses pescadores têm vivenciado em outras unidades de conservação de Proteção Integral, a exemplo do Parque Nacional da Lagoa do Peixe, Rio Grande do Sul, e da Reserva Biológica Marinha do Arvoredo, em Santa Catarina, possuem também um papel fundamental para se compreender os posicionamentos contrários à Resex, uma vez que eles desconhecem as diferentes categorias de UCs. Além disso, nos dois contextos os pescadores atribuem à $\mathrm{APA} B \mathrm{BF}$ e seus parceiros o papel de protagonista no processo para a criação das Resex. Criar a Resex significa assim "entregar" a gestão do território à APA BF e seus parceiros locais envolvidos diretamente no pleito pelas Resex - seja a ASPECI e o Fórum da Agenda 21 Local da Lagoa de Ibiraquera, no caso da Resex da Pesca Artesanal de Imbituba e Garopaba, ou a ONG Rasgamar, no caso da Resex do Cabo de Santa Marta.

\subsection{Síntese analítica das representações sociais sobre Reserva Extrativista}

As representações sociais elucidadas acima oferecem elementos chave para se refletir sobre a etapa pré-implementação de Resex Mar. Como vimos, um dos pré-requisitos fundamentais para a criação das primeiras Resex amazônicas foi a presença de organização social dos futuros beneficiários dessa política pública, assim como o conhecimento sobre o que vem a ser uma Resex (Alegretti, 2002). No contexto da zona costeira, porém, a demanda pelas Resex Mar por diferentes grupos de pescadores locais nos colocam outros desafios, considerando-se os diferentes usos, conflitos e pressões a que tem sido submetida essa porção do território. Ademais, os pescadores artesanais, sempre mantiveram uma relação de tutela junto ao Estado (Callou, 2011), de modo que a autonomia e o reconhecimento do poder político dos pescadores artesanais na gestão do território se apresenta como um desafio e, como aponta Chamy (2004), ainda carece de legitimidade perante o Estado.

No âmbito institucional, de acordo com a IN ICMBio 03/2007, o pleito pela Resex deve ser formalizado pela população tradicional ou sua representação e, a partir de então, havendo confirmação da presença de população tradicional e a relevância ecológica da área, o processo é formalizado pelo ICMBio. Os dois processos de criação de Resex estudados cumpriram todas as etapas formais prescritas pela legislação. Contudo, entre a lei e a realidade social, há um universo a ser desvelado. Os pescadores artesanais, divididos em dois grupos, elaboraram representações sociais distintas a respeito da política pública Resex, ressignificando 
o conceito de Resex em referência aos seus modos de vida, visões de mundo e conhecimentos específicos. Esse processo ocorreu em meio às interações sociais tecidas entre os diferentes atores imersos no tecido social local, e ao longo do processo os grupos se posicionaram de maneira antagônica. Com a intensificação dos antagonismos, os grupos sociais passaram a se cristalizar, e o conflito social atuou como uma força centrípeta, garantindo a unidade de cada grupo social (Simmel, 1983).

O conteúdo das representações sociais mantém uma relação de interdependência com as práticas e interações sociais locais, assim como, em relação ao contexto mais amplo de consolidação e implementação da legislação ambiental brasileira. Nesse sentido, o conteúdo das representações sociais nos casos estudados revela que, para os pescadores que pleiteiam a Resex, ela se configura como uma resposta para o conflito entre pesca artesanal e industrial, assim como a delimitação de territórios específicos para grupos de pescadores locais, a exemplo da Laje do Campo Bom, no Farol de Santa Marta.

A inclusão de terras nos limites das Resex, com exceção dos terrenos de marinha, foi vista com ressalvas por todos os pescadores, sobretudo por aqueles que lideraram o processo. No entanto, esse discurso focado na gestão do recurso, limitando o território da Resex à lâmina d'água, mais do que expressar uma demanda original dos pescadores artesanais, é fruto de uma construção e negociação social junto ao ICMBio. A criação de reservas extrativistas estritamente marinhas tem sido o resultado de uma ação estratégica do órgão ambiental, como revela o Coordenador Geral das Resex (CGREX/ ICMBio), na época de criação das mesmas:
Isso foi uma decisão estratégica tomada pra garantir a decretação o mais rápido possível. Porque todos os processos que se incluiu alguma parte de moradia os conflitos com os veranistas, as comunidades não locais, atingiam tal complexidade que acabavam inviabilizando a criação das unidades. Ai passamos a utilizar o conceito de criação do espaço de mobilização do bem ambiental, a partir dos terrenos de marinha, pra tentar acelerar esses processos e remover esses empecilhos. (...)A nossa ideia era que esse grupo tendo o seu espaço de mobilização do bem ambiental garantido, pudesse se fortalecer e poder retomar sua área de moradia, etc., mas nem sempre isso se deu. (Informação verbal)

Se por um lado, para os pescadores favoráveis, a presença do Estado na gestão dos seus territórios mitigaria os conflitos entre a pesca artesanal e industrial; por outro lado, os pescadores que se posicionam contra a Resex, em sua maioria pescadores das lagoas, apesar de também compartilharem uma percepção sobre os problemas relacionados à pesca, não veem a Resex como uma forma de resolver e/ou minimizá-los. Para esses, a Resex viria a intensificar os conflitos, uma vez que haveria a perda de autonomia territorial, constituindo-se em um espaço do Estado, gerido pelos interesses das agências ambientais e seus parceiros locais.

Como mencionado acima, essas representações sociais ocorrem em meio às práticas e interações dos diferentes atores sociais. No caso estudado, os pescadores artesanais formam alianças com atores sociais que marcam posições antagônicas frente ao cenário do desenvolvimento local. Os grupos de pescadores que se posicionam contrários à Resex expressam uma visão negativa das organizações governamentais e não-governamentais ligadas à conservação ambiental. Aliam-se assim a atores sociais dos setores governamental e privado que dão suporte a uma dinâmica de desenvolvimento econômico que privilegia o turismo de massa e às 
atividades portuárias. Por outro lado, os grupos de pescadores artesanais favoráveis às Resex representam um grupo mais restrito, que em sua maioria percebe as agências ambientais, sobretudo o ICMBio e a APA BF, como possíveis aliadas.

Por fim, vale fazer uma reflexão mais ampla sobre a maneira como a política Resex "aporta" no território de grupos sociais diferenciados culturalmente. O reconhecimento pelo Estado dos direitos das populações tradicionais ${ }^{11}$ e a valorização dos seus saberes no processo de gestão ambiental se configuram avanços importantes na legislação ambiental brasileira, historicamente marcada pela primazia do preservacionismo (Diegues, 2004). Nesse sentido, tais avanços criam (ou deveriam criar) oportunidades para que essas populações possam participar mais ativamente das decisões relativas ao seu próprio futuro. Contudo, esse reconhecimento acontece sob certas condições, uma vez que seus modos de vida devem estar em sintonia com um estilo de vida sustentável (Mendes, 2009).

Nos casos das Resex estudadas, a imagem construída junto às comunidades sobre a categoria "extrativista" e o "ser tradicional" evocou um "estilo de vida sustentável" típico de "comunidades rústicas" (Cândido, 2010), que não condiz com a realidade do pescador artesanal do litoral centro-sul catarinense. Para os grupos contrários, a Resex representa perda de autonomia de gestão do território, que passaria a ser gerido por interesses estritamente ambientais, impondo aos pescadores um modo de vida "extrativista". Desse modo, um dos grandes desafios é inserir as relações socioculturais, que se estabelecem no território, na composição do que vem a ser população tradicional beneficiária da Resex.

Diante dessas ambivalências, os pescadores artesanais ancoram suas representações sociais na imagem que compartilham sobre as práticas dos principais atores sociais locais da conservação ambiental. Nesse sentido, o ICMBio, representado pela APA BF e suas práticas de conservação da biodiversidade ganha centralidade. A Resex é vista por esses pescadores como mais uma categoria de UC, seja, por um lado, para a gestão dos recursos pesqueiros, ou, por outro lado, para impor restrições ambientais aos seus modos de vida. Sendo assim, as principais propostas que orientaram os movimentos sociais na construção da política Resex, sobretudo a luta pela autonomia na gestão de seus territórios, permaneceram em segundo plano. Nesse sentido, as duas representações sociais dos pescadores artesanais demonstram que a Resex permanece como uma política de fora, na qual os protagonistas não são os pescadores artesanais. Os processos de criação foram frágeis no sentido de criar espaços de diálogo entre os diferentes grupos sociais, e possibilitar o entendimento sobre os direitos e deveres inerentes ao arcabouço legal que orienta as Resex. Finalizado o processo formal junto às comunidades locais, permanece entre os pescadores visões antagônicas e parciais acerca do significado e implicações do processo de criação e implementação dessa política pública.

\section{Considerações finais}

A política pública Reserva Extrativista tem passado por profundas transformações desde a

${ }^{11}$ Cf. Creado et al. (2008); Castro, et al. (2006); Mendes (2008; 2009); Lobão (2010). 
sua concepção no seio do movimento social dos seringueiros. A transposição deste modelo para o bioma marinho trouxe novos desafios tanto para os processos de criação quanto para a implementação dos diferentes instrumentos de gestão.

Os processos de criação de duas Resex no litoral centro-sul de Santa Catarina revelam que um dos principais desafios é relativo à própria construção do conceito de Resex e os seus desdobramentos junto aos grupos sociais que deveriam ser os principais protagonistas deste processo: os pescadores artesanais.

A teoria das representações sociais se mostrou bastante frutífera para se desvelar os posicionamentos e conflitos sociais com a vinda das Resex, trazendo à luz o conhecimento compartilhado pelos pescadores artesanais na dinâmica social engendrada durante a etapa pré-implementação. A realização de estudos dessa natureza pode contribuir para clarear as representações sociais que tendem a ficar submersas nas dinâmicas sociais, possibilitando assim, uma reflexão crítica e embasada sobre o próprio processo de criação de Resex. Ademais, tais reflexões podem contribuir para se repensar os processos de concepção dos seus instrumentos de gestão e sua implementação, no sentido de favorecer um diálogo horizontal entre os objetivos da conservação ambiental e os direitos das populações tradicionais.

\section{Agradecimentos}

Agradeço à CAPES pelo apoio financeiro e ao Laboratório de Psicologia Social da Comunicação e Cognição (LACCOS/UFSC) por gentilmente analisar a análise textual dos dados da pesquisa no Software Alceste.

\section{Referências}

Abric, J. C. Abordagem estrutural das representações sociais: desenvolvimentos recentes. In: Campos, P. H. F.; Loureiro, M.C.S. (Orgs.). Representações sociais e práticas educativas. Goiânia: Ed. Da UCG, p. 37-57, 2003.

Acselrad, H. Ambientalização das lutas sociais - o caso do movimento por justiça ambiental. Estudos Avançados, 24(68), 103-119, 2010. doi:10.1590/S010340142010000100010

Adriano, J. Rumo ao ecodesenvolvimento na zona costeira catarinense: estudo de caso sobre a experiência do Fórum da agenda 21 Local da Lagoa de Ibiraquera. Florianópolis, Dissertação (Mestrado em Sociologia Política) - UFSC, 2011.

Albuquerque, L. Conflitos socioambientais na zona costeira catarinense: estudo de caso da barra do Camacho/SC. Florianópolis, Tese (Doutorado em Direito) - UFSC, 2009.

Allegretti, M. H. A Construção Social de Políticas Ambientais: Chico Mendes e o Movimento dos Seringueiros. Brasília, Tese (Doutorado em Desenvolvimento Sustentável - Gestão e Política Ambiental) - UNB, 2002.

Brasil. Lei n. ${ }^{\circ}$ 9.985, de 18 de julho de 2000. Dispõe sobre o Sistema Nacional de Unidades de Conservação.

Brasil. Decreto Federal s/nº 2000 . Cria a Área de Proteção Ambiental Baleia Franca. Disponível em: https://conapabaleiafranca.files.wordpress.com/2016/10/decreto-criac3a7c3a3o-apabf-_2000.pdf.

Bucci, T. Implementação da Reserva Extrativista marinha do Corumbau/BA: Relações de atores e processos de mudanças. Ilhéus, Dissertação (Mestrado em Desenvolvimento Regional e Meio Ambiente) - UESC, 2009.

Callou, A. B. Povos do mar: herança sociocultural e perspectivas no Brasil. Ciência e Cultura, 62(3), 2010. Disponível em: http://cienciaecultura.bvs.br/pdf/cic/v62n3/ a18v62n3.pdf. 
Camargo, B. V. Alceste: um programa informático de análise quantitativa de dados textuais. In: Moreira, et al. (Orgs.). Perspectivas teórico-metodológicas em representações sociais. João Pessoa: UFPB, p. 511-539, 2005.

Camargo, V. B.; Barbará, A.; Bertoldo, R. B. Concepção pragmática e científica dos adolescentes sobre a aids. Psicologia em Estudo, 12(2), 277-284, 2007.

Cândido, A. Os parceiros do Rio Bonito. Rio de Janeiro, Ed. Ouro sobre Azul, 2010.

Castro, de F. et al. Use and Misuse of the concepts of traditional and property rights in the conservation of natural resources in the Atlantic Forest (Brazil). Ambiente \& Sociedade. 9, 2006. Disponível em: http://www.scielo.br/scielo. php?script=sci_arttext\&pid=S1414-753X2006000100002

Capellesso, A. J. Os sistemas de financiamento na pesca artesanal: um estudo de caso no litoral centro-sul catarinense. Florianópolis, Dissertação (Mestrado em Agroecossistemas) - UFSC, 2010.

Chamy, P. Reservas Extrativistas Marinhas como instrumento de reconhecimento do direito consuetudinário de pescadores artesanais brasileiros sobre territórios de uso comum. In: Anais Conference of the International Association for the Study of Common Property: México, 2004. Disponível em: http://www.ibcperu.org/doc/isis/5275.pdf

Chuenpagdee, R.; Jentoft, S. Step zero for fisheries co-management: What precedes implementation. Marine Policy, 31, 657-668, 2007.

Creado, E .S. J. et al. Entre "tradicionais" e "modernos": negociações de direitos em duas unidades de conservação da Amazônia brasileira. Ambiente \& Sociedade, 11(2), 2008. Disponível em: http://www.scielo.br/pdf/asoc/v11n2/ v11n2a04.pdf

Diegues, A. C. Pescadores, camponeses e trabalhadores do mar. São Paulo, Ática, 1983.

Diegues, A. C. O Mito moderno da natureza intocada. São Paulo, Hucitec, 2004.

Doise, W. Atitudes e representações sociais. In: Jodelet, D. (Org.). As representações sociais. Rio de Janeiro: EdUERJ, p. 187-203, 2001.
Gerhardinger, L. C. Inovação, governabilidade e protagonismo de pessoas-chave na Área de Proteção Ambiental da Baleia Franca (Santa Catarina, Brasil). Campinas, Tese (Doutorado Ambiente \& Sociedade) - UNICAMP, 2014.

ICMBIO. Instrução Normativa $\mathrm{N}^{\circ} 03$, de 18 de Setembro de 2007. Disciplina as diretrizes, normas e procedimentos para a criação de Unidade de Conservação Federal das categorias Reserva Extrativista e Reserva de Desenvolvimento Sustentável. Disponível em: http://www.mma. gov.br/estruturas/240/_arquivos/in_icmbio_03_criao_resex_e_rds_pdf_240.pdf.

Jodelet, D. As representações sociais. Rio de Janeiro, UERJ, 2001.

Jodelet, D. Representações sociais: história e avanços teóricos - vinte anos da teoria das representações sociais no Brasil. In: Oliveira, D. C.; Campos, P. H. F. (Orgs.). Representações sociais: uma teoria sem fronteiras. Rio de Janeiro: Museu da República, p.11-22, 2005.

Lobão, R. J. da S. Reservas Extrativistas Marinhas: uma reforma agrária no mar? Uma discussão sobre o processo de consolidação da Reserva Extrativista Marinha de Arraial do Cabo/RJ. Niterói, Dissertação (Mestrado em Antropologia) - UFF, 2000.

Lobão, R. J. da S. Cosmologias Politicas do Neocolonialismo: como uma Política Pública pode se transformar em uma Política do Ressentimento. Rio de Janeiro: Editora da UFF, 2010.

Mendes, A. B. V. Ambientalização de direitos étnicos e etnização das arenas ambientais: populações tradicionais e povos indígenas da Reserva de Desenvolvimento Sustentável de Mamirauá (AM). In: Anais da $26^{a}$ Reunião Brasileira de Antropologia, Porto Seguro, 01 a 04 de junho, 2008.

Mendes, A. B. V. Conservação ambiental e direitos multiculturais: reflexões sobre justiça. Campinas, Tese (Doutorado Ambiente \& Sociedade) - Unicamp, 2009.

Moscovici, S. On social representation. In: Forgas, P. P. (Org.). Social Cognition. London: Academic, 1982.

Nicolau, O. Ambientalismo e Carcinicultura: disputas de "verdades" e conflito social no Extremo Sul da Bahia. Dissertação (Mestrado em Desenvolvimento, Agricultura 
e Sociedade). Rio de Janeiro - UFRRJ, 2006.

Pinto da Silva, P. From common property to co-management: lessons from Brazil's first maritime extractive reserve. Marine Policy, 28(5), 2004.

Pomeroy, R. S; Rivera-Guieb, R. Fishery Co-management: A Practical Handbook. Otawa: IDRC, 2006.

Quivy, R.; Campenhoudt, L. V. Manual de investigação em ciências sociais. Lisboa: Gradiva, 1992.

Rosar, D. B. Gestão participativa e política substantiva: duas formas de ação política coexistentes em Ibiraquera (Imbituba/Garopaba - SC). Florianópolis, Dissertação (Mestrado em Agroecossistemas) - UFSC, 2007.

Sá, C. A teoria do núcleo central das representações sociais. In: Sá, C. Núcleo central das representações sociais. Petrópolis: Vozes, pp. 51-98, 1996.

Seixas, C. S.; Kalikoski, D. C. Gestão participativa da pesca no Brasil: levantamento das iniciativas e documentação dos processos. Desenvolvimento e Meio Ambiente, 20, 119-139, 2009.

Simmel, G. Sociologia. In: Filho, E. de M. (Org.). Georg Simmel: Sociologia. São Paulo: Ática, 1983.

Soares, C. Em torno do pensamento social e do conhecimento do senso comum. A aplicação da metodologia Alceste em contextos discursivos distintos. In: Moreira, A. S. P. (Org.). Perspectivas teórico-metodológicas em representações sociais. João Pessoa: UFPB, p. 541-571, 2005.

Socioambiental Consultores Associados et al. Estudos para a criação da Reserva Extrativista Marinha do Cabo de Santa Marta, com diretrizes de manejo. Florianópolis, 2005.

Spínola, J. L. Participação e deliberação na Resex Marinha do Pirajubaé (SC). Curitiba, Tese (Doutorado Interdisciplinar em Meio Ambiente e Desenvolvimento)-UFPR, 2011.

Teixeira, M. C. T. V.; Schulze, C. M. N; Camargo, B. V. Representações sociais sobre a saúde na velhice: um diagnóstico psicossocial na Rede Básica de saúde. Estudos de Psicologia, 7(2), 351-359, 2002.

Vivacqua, M. Reservas Extrativistas Marinho-Costeiras: reflexões sobre o estágio pré-implementação. Ambiente \& Sociedade, 21, 2018. Disponível em: http://www.scielo.br/ pdf/asoc/v21/pt_1809-4422-asoc-21-e00323.pdf

Wachelke. J. F. R.; Camargo, B. V. Representações sociais, representações individuais e comportamento. Revista Interamericana de Psicologia, 41(2), 379-390, 2007. 